\title{
Multi-Level Approach of the Ecotoxicological Impact of a Combined Sewer Overflow on a Peri-Urban Stream
}

\author{
Céline Becouze-Lareure $^{1,2^{*}}$, Christine Bazin ${ }^{2}$, Philippe Namour ${ }^{3,4}$, Pascal Breil ${ }^{5}$, Yves Perrodin ${ }^{1}$ \\ ${ }^{1}$ Laboratoire d'Ecologie des Hydrosystèmes Naturels, Université de Lyon, Vaulx-en-Velin, France \\ ${ }^{2}$ Insavalor, Division Polden, Villeurbanne, France \\ ${ }^{3}$ Institut des Sciences Analytiques, Université de Lyon, Université Claude Bernard Lyon 1, Villeurbanne, France \\ ${ }^{4}$ Irstea (Cemagref), Unité de Recherche en Milieux Aquatiques Écologie et Pollutions, Lyon, France \\ ${ }^{5}$ Irstea (Cemagref), Unité de Recherche Hydrologie Hydraulique, Lyon, France \\ Email: *celine.becouze@insa-lyon.fr
}

Received August 20, 2012; revised September 28, 2012; accepted October 18, 2012

\begin{abstract}
In periurban zones, urban wet weather discharges have been recognized as the most significant vector of pollution in aquatic environments. The discharge of this water without treatment into the aquatic environment could present an ecotoxicological risk for biocenosis. The aim of the INVASION project is to assess the potential ecotoxicological impact of a combined sewer overflow (CSO) on a peri-urban stream. A comparative study between upstream and downstream areas of the CSO allowed observing significant effects of this overflow on the river. We studied three layers of stream: surface water, benthic layer and hyporheic layer. To characterize the potential ecotoxicological risk of water and sediments, we used a battery of 4 bioassays: Daphnia magna, Vibrio fischeri, Brachionus calyciflorus and Heterocypris incongruens. In parallel, we measured the physico-chemical parameters: ammonium $\left(\mathrm{NH}_{4}^{+}\right)$, chromium $(\mathrm{Cr})$, copper $(\mathrm{Cu})$ and lead $(\mathrm{Pb})$. An ecological risk is greatest for the hyporheic zone in downstream river, particularly for the solid phase. These results corroborated with the physico-chemical data obtained.
\end{abstract}

Keywords: Combined Sewer Overflow; Ecotoxicity; Pollutants; Stormwater; Stream; Urban Wet-Weather Flow

\section{Introduction}

The general development of urban areas is generating increasing flows of pollutants in aquatic environments from urban drainage networks and stormwater management systems [1]. This water that flows into aquatic environments during wet weather conditions is defined as urban wet-weather discharges (UWWD). The release of these pollutants into the natural environment has a number of consequences such as visible pollution from floating debris, increased turbidity due to suspended solids, deoxygenation of the environment from the inflow of biodegradable organic matter and nitrates, and a potential toxic effect on aquatic environments through the widespread or localised inflow of chemical substances [2,3].

Most investigations on UWWD evaluated the quality of discharges at catchment outlet in case of separate systems or at overflow structures in case of combined systems. Concentrations and loads of main constituents and priority substances of European Water Framework Directive [4] have been well documented. These last years, several research projects like ESPRIT [5], ScorePP [6]

"Corresponding author. aimed to contribute to the identification, evaluation and characterization of priority substances transported by stormwater. These effluents therefore need to be factored into plans for the management and treatment of urban wastewater. This generally proves to be an arduous task due to their strong spatiotemporal variability in terms of quality and quantity, and the high degree of uncertainty involved in their evaluation [7].

In certain circumstances, the direct discharge of urban wet-weather flow into aquatic environments can lead to ecotoxicological risks, which need to be evaluated so that the appropriate processing measures can be implemented.

However, there is a shortage of data in the literature on the ecotoxicological characterisation of urban wet-weather flow [8,9]. In the study by Marsalek et al. (1999) [8], several variants (combined/separate sewer system, several events in time, sediments, mixed samples) were tested using a battery of eight bioassays.

This work highlighted the usefulness of characterising these effluents using a battery of bioassays for a better appreciation of their intrinsic ecotoxicity.

The main objective of our study was to presented a new approach to evaluate the ecotoxicological impact of 
a combined sewer overflow (CSO) on the Chaudanne, a peri-urban stream situated in a peri-urban drainage basin in the Lyon area of France.

In a first time, we had tested a bioassay battery on river samples. The ecotoxicological assays realized in order to assess the sample on "representative" organisms of the ecosystem. We had been chosen to characterize the ecotoxicological risks by mono-specific assays realized in laboratory. The aquatic organisms used come from breeding in laboratory or sporocysts bough in the shop.After validation of bioassays, we evaluate three layers of stream, surface water, benthic and hyporheic layers, through a comparative study of sampling sites both upstream and downstream of the CSO and to more accurately identify the zones (surface water, benthic zone and hyporheic zone) that pose the greatest risks to aquatic organisms. Lastly, a comparison between ecotoxicological results and physico-chemical parameters $\left(\mathrm{NH}_{4}^{+}, \mathrm{Cr}, \mathrm{Cu}\right.$ and $\mathrm{Pb}$ ) was carried out, in order to explain the possible toxicity of the samples.

\section{Materials and Methods}

\subsection{Study Site}

The Chaudanne is a small, $2.5 \mathrm{~km}$-long stream in the western part of Lyon (Figure 1). At the outlet of the CSO of the village of Grezieu-la-Varenne, the drainage basin covers a surface area of $2.7 \mathrm{~km}^{2}$. It is rural, mainly pastoral. The urban downstream portion has a smaller surface area $\left(0.44 \mathrm{~km}^{2}\right.$, or $\left.16 \%\right)$. The Chaudanne stream has an average flow rate of $30 \mathrm{~L} / \mathrm{s}$. This rate exceeds several hundred litres during heavy storms and can reach a rate of around $1500 \mathrm{~L} / \mathrm{s}$ when there is heavy flooding in the basin. Its flow rate is generally zero during the 4 summer months, but with a permanent underflow in the hyporheic zone. Three zones characterize the stream:

- A flat zone consisting of grit and certain organic elements where the flow velocity is low;

- A "riffle" segment characterised by a mixture of stone, pebbles and blocks where the flow velocity is high;

- A 30-cm deep pool composed of grit and stones,
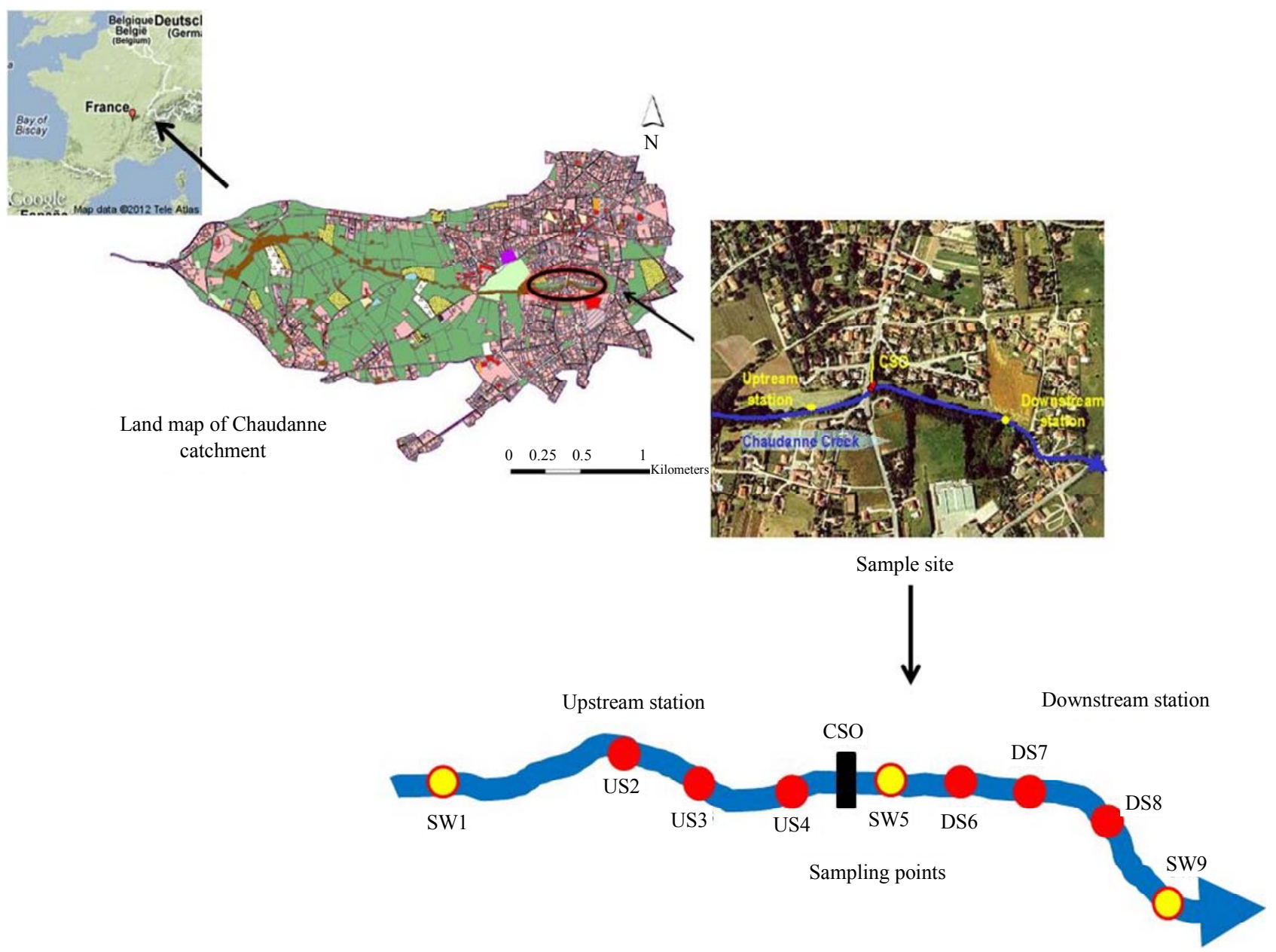

Figure 1. Location of sampling sites upstream (US) (left) and downstream (DS) (right) of the Grézieu-la-Varenne CSO on the Chaudanne, a peri-urban stream. Yellow circles: sampling of surface water only; red circles: samples from the run-riffle-pool sequence in the benthic and hyporheic zones. 
where the flow velocity is very lowSampling zones.

For sampling sites 2 to 4 and 6 to 8 , two different zones were sampled: the benthic zone (B) and the hyporheic zone (H). Surface water (SW) samples were only collected at sites 1,5 and 9. Samples were collected in an upstream direction at each site to avoid environmental disturbance (Figure 1).

The surface water samples were collected in a plastic 5 L container. The benthic zone corresponded to the first five superficial centimetres of the streambed and collected using a flat-bottomed hand dredge developed by the Cemagref-Lyon. It was used to carefully scrape the benthic zone to a depth of around $5 \mathrm{~cm}$ in order to collect the sediment, which was then transferred into a $2 \mathrm{~L}$ polypropylene container, and preserved on ice until it arrived at the laboratory.

The hyporheic zone samples were extracted using the Bou-Rouch pumping method [10], enabling them to be collected from a depth of approximately $30 \mathrm{~cm}$ under the streambed. This involved creating suction in order to maintain adequate interstitial flow into the holes of a pipe and to collect the samples from the hyporheic zone. For each sample, $10 \mathrm{~L}$ of hyporheic water were pumped from a depth of $30 \mathrm{~cm}$ below the spring bed, and the two last litres were sampled.

For the benthic and hyporheic zone samples, we decided to study the "water" phase and the "particle" phase separately. Each sample was homogenised and the two phases were then separated by decantation $(1 \mathrm{~h})$ at room temperature. The "water" phase consisted of water and the finest suspended particles. The "particle" phase consisted of larger particles that remained at the bottom of the container.

The samples were stored in a freezer at $-18^{\circ} \mathrm{C}$ whilst carrying out the various measurements.

\subsection{Ecotoxicity Tests}

The ecotoxicological characterisation of the samples was carried out using a battery of additional bioassays (or ecotoxicity tests). These tests involved exposing a population of aquatic organisms to an effluent at increasingly high concentrations in order to determine the concentration level at which toxic effects were induced. The chosen battery adapted for the evaluation of the potential ecotoxicological impact of urban and industrial effluents on aquatic environments, and previously tested in other studies various samples: urban wet weather discharge [9], hospital effluents [11], dredged materials [12] and marine dredged materials [13]. The battery consists of four bioassays: Daphnia magna (Dm), Vibrio fischeria (Vf), Brachionus calyciflorus $(\mathrm{Bc})$ and Heterocypris incongruens (Hi). The characteristics (organism, trophic level, etc.) of these four bioassays are listed in Table 1.

Dm is a standard assay accepted to determine the acute toxicity of aqueous matrix or substances in solution [14] [15]. Vf accepted as simple, reliable and rapid assay, moreover it is normalized. The two others assays, $\mathrm{Bc}$ and $\mathrm{Hi}$, are normalized.

The experimental data process by using adapted tool like software to determine the $\mathrm{CE}_{20}$ values for tested samples. It should be noted that the smaller the value, the more toxic the sample to the organism in question. The Hi test no realized on dilution range, so it is not possible to determine a $\mathrm{CE}_{20}$ value for tested sample. The results will be expresses in percent of effect observed.

\subsection{Measurement of Physico-Chemical Parameters}

The physico-chemical characterisation of the samples was performed in the laboratory on the 3 sampled zones (superficial, benthic and hyporheic). Based on the preliminary results of the characterisation of chemical contaminants discharged into the stream by urban wetweather flow and on our study objective [16], a list of evaluation parameters was drawn up: 3 metals, chromium $(\mathrm{Cr})$, copper $(\mathrm{Cu})$ and lead $(\mathrm{Pb})$, ammonium $\left(\mathrm{NH}_{4}^{+}\right)$and total suspended solid (TSS). The $\mathrm{Cr}$ and $\mathrm{Cu}$ in trace amounts are essential for organisms but in negligible

Table 1. List of parameters evaluated in this study.

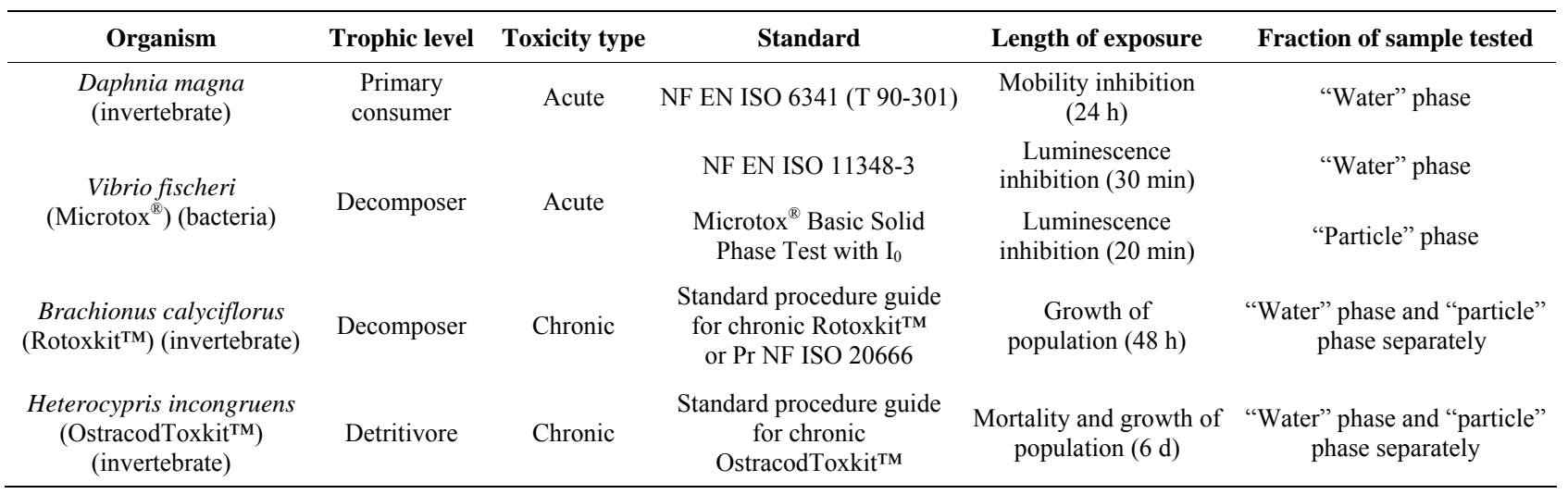


quantity. Their increase in the environment can lead to the toxicity impacts. However, others metals, like $\mathrm{Pb}$, are not necessary and have toxic effects. The ammonium was chosen for its presence in urban wet weather discharge. The concentration of this ion in receiving waters is dependant of $\mathrm{pH}$ and can lead to the formation of $\mathrm{NH}_{3}$ which is the form the most toxic.

Laboratory testing was performed in the CARSO laboratory in Lyon. Metals analysed in particle phase according to M_ST006 and NF EN ISO11885 and ammonium analysed in water phase according to NT T90-015-2.

\section{Results}

\subsection{Rainfall Campaign}

Samples were collected on Monday $15^{\text {th }}$ November 2010 (Figure 2). There were 4 storm events between 15/10/ 2010 and 15/12/2010. The flow rate of the stream before the samples were collected was in the region of $20 \mathrm{~L} \cdot \mathrm{s}^{-1}$. At the time of sampling, the flow rate of the Chaudanne was approximately $400 \mathrm{~L} \cdot \mathrm{s}^{-1}$. This peak can be attributed to the storm event due to the quantity of stormwater $\left(I_{\max }\right.$ $\left.=19 \mathrm{~mm} \cdot \mathrm{h}^{-1}\right)$, the surface runoff and the inflow from the CSO. The maximal flow rate measured at the CSO outlet was $72 \mathrm{~L} \cdot \mathrm{s}^{-1}$.

Before the sampling period, low flow peaks were observed in the stream. These can be explained by the discharge from the CSO.

\subsection{Ecotoxicological Characterisation}

\subsection{1. “Aquatic" Sample}

$\mathrm{Dm}$ and Vf acute toxicity tests revealed no toxicity of this type in any of the samples analysed. For the chronic toxicity test (48 $\mathrm{h} \mathrm{Bc})$, the surface water samples and the "water" samples from the benthic zone downstream of the CSO revealed no toxicity for the organisms tested. However, for the "water" samples from the hyporheic zone collected upstream of the CSO, a significant level of toxicity was found in the organisms tested $\left(\mathrm{EC}_{20}\right.$ value between $20 \%$ and $70 \%$ of sample).For the Hi chronic toxicity test, we observed for surface water samples a toxicity in this order: SW9 $>\mathrm{SW} 1 \approx \mathrm{SW} 5$.

The water phase of benthic zone, based on mortality of $\mathrm{Hi}$, the percentages obtained are insignificant compared to the accepted reference threshold. With regard to organism growth, the size of the organisms was similar to those obtained for the control (US3BW) for the sites above the CSO. The samples downstream of the CSO can be placed in order of toxicity as follows: DS7BW $\approx$ DS8BW > DS6BW.

For water phase of hyporheic zone, organism mortality was not significant compared to the reference threshold $(20 \%)$ for the upstream and downstream sites. On the basis of growth inhibition, the samples collected above the CSO can be classified in the following order of toxicity: US4HW $\approx$ US3HW $>$ US2HW. A higher inhibition was observed for sample DS6HW collected directly below the CSO (34\%). A decrease in inhibition was noted for the other two downstream samples (21\% and 17\%).

\subsection{2. "Particle" Sample}

The results of the 20-min Vf test performed on the benthic (particles washed through 2-mm sieve) and hyporheic samples demonstrated that they were non-toxic to this organism for the 6 stations studied.
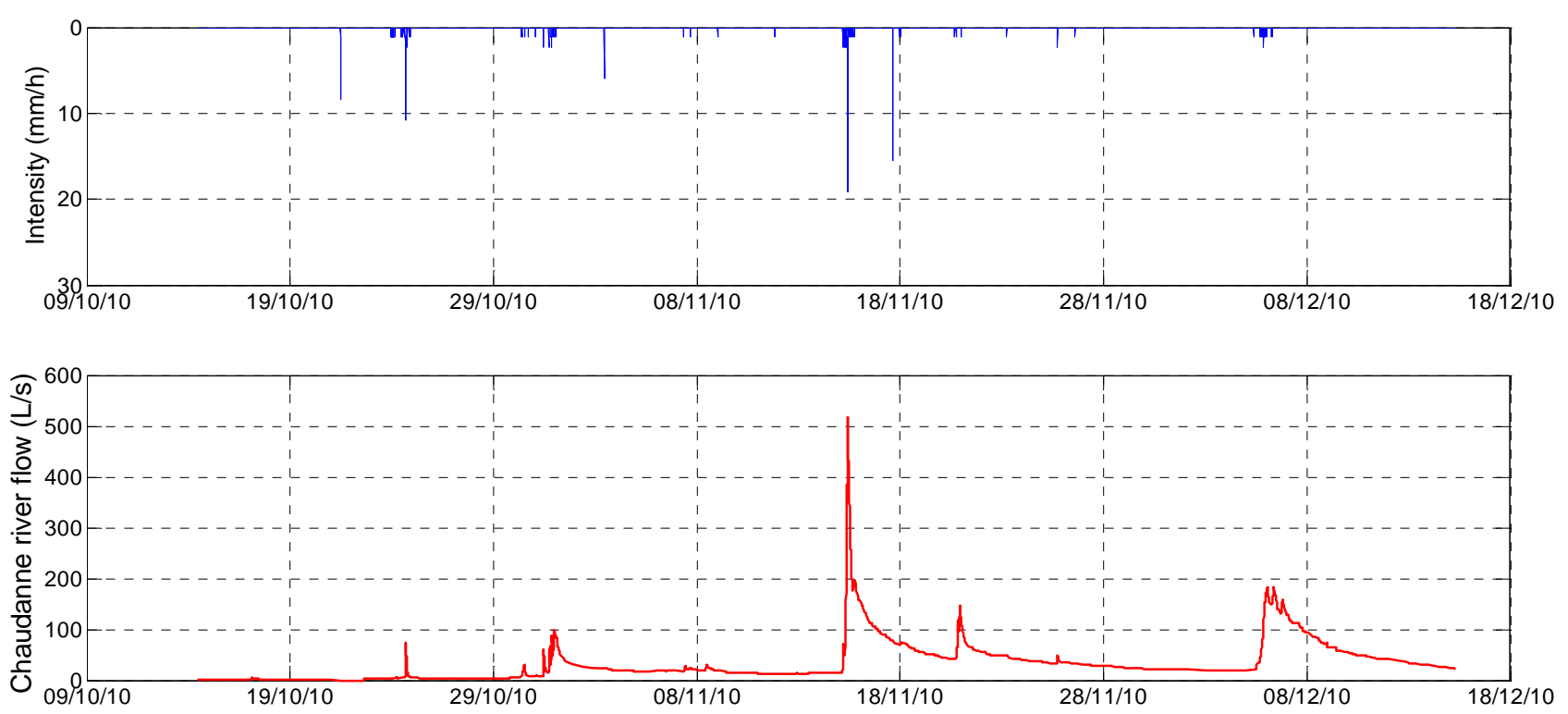

Figure 2. Rainfall and flow rate data (Chaudanne stream and CSO) for the period from 15/10/2010 to 15/12/2010 ( 1 sampling date: 15/11/2010) (Data obtained by the Cemagref-Lyon as part of the OTHU). 
The acute toxicity test, $48 \mathrm{~h}-\mathrm{Bc}$, realized on hyporheic particle show a significant level of toxicity in the samples collected downstream of the CSO with $\mathrm{EC}_{20}$ values ranging between $4 \%$ and $10 \%$. This test highlighted the much higher level of toxicity of the "particle" phase compared to the "aquatic" phase.

The Hi test showed a toxicity for particle benthic and hyporheic. For benthic zone, mortality percentages in samples US4BP and US7BP were the same or slightly lower than the threshold value of $20 \%$ (28\% and $20 \%$ respectively). With regard to growth inhibition, the size of the organisms in the samples collected from above the $\mathrm{CSO}$ was similar to those in the control. Below the CSO, a marked increase in inhibition was observed with a percentage of $34 \%$ for site DS8BP.

According to hyporheic zone, mortality was insignificant based on the reference threshold at the upstream sites. For the downstream samples, significant mortality was recorded for sample DS8HP $(65 \%)$. Based on organism growth, the inhibition percentages obtained for the downstream samples were higher than those obtained for the upstream samples. Upstream, inhibition varied between $36 \%$ and $41 \%$ whereas downstream it ranged from $50 \%$ to $69 \%$. Sample DS7HP was the most toxic to the organisms tested.

\subsection{Metal Concentrations in the Particle Fraction}

\subsubsection{Benthic Zone}

Figure 3 shows the results of metal concentrations in the benthic sediments, upstream and downstream of the CSO.
For the upstream sites, mass concentrations were similar for all 3 metals $(\mathrm{Cr}, \mathrm{Cu}$ and $\mathrm{Pb})$. Average concentrations of $\mathrm{Cr}, \mathrm{Pb}$ and $\mathrm{Cu}$ were 16,8 and $4 \mu \mathrm{g} / \mathrm{g}$ respectively. Immediately below the CSO at sampling site DS6, concentrations increased significantly (by a factor of 3 for $\mathrm{Cr}, 14$ for $\mathrm{Pb}$ and 12 for $\mathrm{Cu}$ ). At the other two downstream sites (DS7 and DS8), the concentrations recorded were lower compared to those measured upstream, except for $\mathrm{Pb}$ at site DS7 where concentrations were even higher. This peak concentration can be attributed to the direct discharge from the $\mathrm{CSO}$ at the time of sampling.

\subsubsection{Hyporheic Zone}

Figure 4 shows the results of the metal concentrations measured in the hyporheic zone sediments for the 6 sampling stations.

The concentrations measured in the upstream hyporheic sediments varied according to the sampling site. Behaviour differed depending on the metal in question. Chromium concentrations were measured between 70 and $49 \mu \mathrm{g} / \mathrm{g}$. Copper concentrations decreased in the downstream direction, from $106 \mu \mathrm{g} / \mathrm{g}$ at site US2 to 60 $\mu \mathrm{g} / \mathrm{g}$ at site US4. A significant increase in lead content was found immediately above the CSO (site US4), from 89 to $260 \mu \mathrm{g} / \mathrm{g}^{-1}$. The accumulation of this metal at this site may be attributable to the "pool" feature favouring this process.

As with the benthic zone, the metal content measured immediately below the CSO (site DS6) was increased (by a factor of 2 compared to site US4 immediately above the CSO). These deposits must have been the result of the direct CSO discharge. At the other two down-

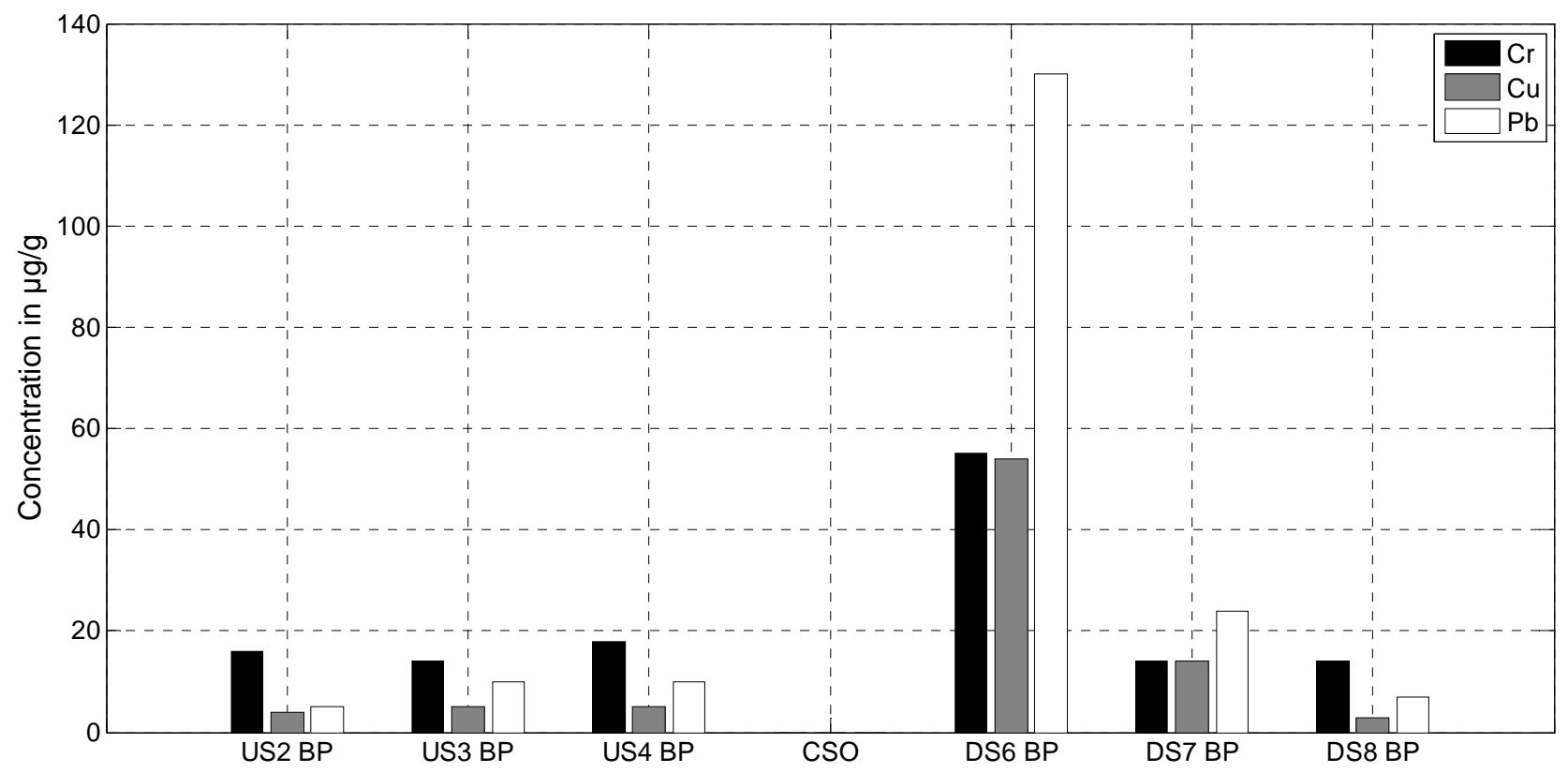

Figure 3. Metal concentrations in the particle fraction of the benthic zone samples. 


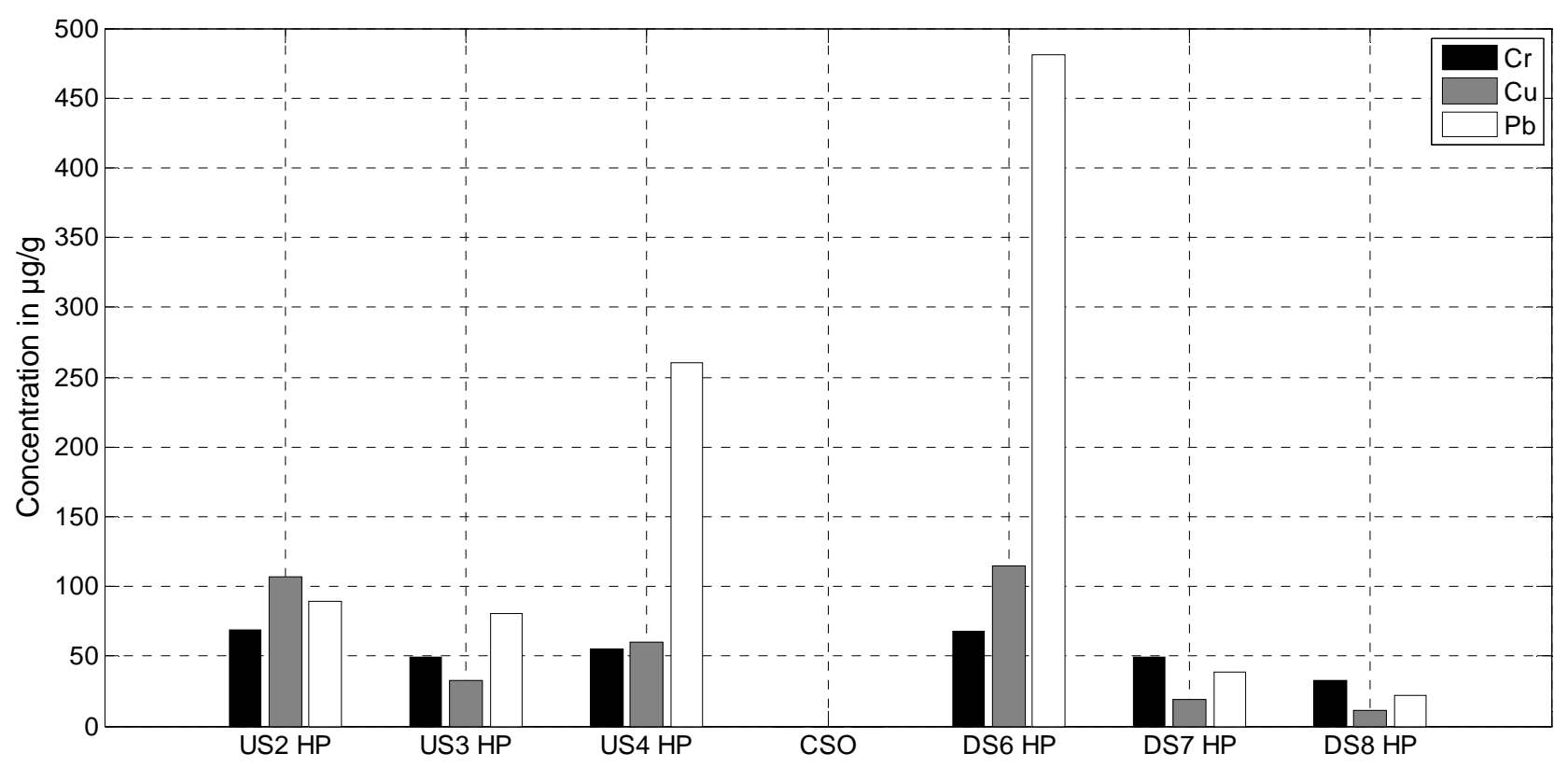

Figure 4. Metal concentrations in the particle fraction of the hyporheic zone samples.

stream sites, concentrations were even lower than those measured upstream of the CSO.

\section{Discussion}

\subsection{Bioassay Ecotoxicity Battery}

The results obtained from the bioassay battery showed the sensitivity of different tests used for the different samples tested. The two acute toxicity tests (Dm and Vf) revealed no toxicity. The $\mathrm{Bc}$ and $\mathrm{Hi}$ tests were complementary. The Bc tests were sensitive for water samples whereas $\mathrm{Hi}$ tests allowed to evaluate the potential ecotoxicological of sediment samples. The bioassay battery used in our study was the same used in Angerville study [9] for urban wet weather discharge sample. The ecotoxicological impact was assessed by $\mathrm{Bc}$ and $\mathrm{Hi}$ tests and allowed to determine the toxicity acute of environmental samples.

\subsection{Impact of CSO on the River}

We compared ecotoxicological characteristics and physico-chemical results of samples collected at sites upstream (US2, US3 and US4) and downstream (DS6, DS7 and DS8) the CSO in order to assess the potential impact of CSO discharge on the different zones of the Chaudanne stream.

\subsubsection{Surface Water}

The pollutant concentrations found in the surface water can, to a large extent, be attributed to the storm event that took place on 15 th November 2010. The suspended solid concentrations in the surface water were generally high and increased slightly from upstream $(441 \mathrm{mg} / \mathrm{L})$ to immediately downstream of the CSO $(546 \mathrm{mg} / \mathrm{L})$. These high concentrations of suspended solids resulted from increased particulate transport in both directions during the storm event (surface runoff and sediment remobilisation), and from the downstream CSO discharge. Ammonium concentrations were relatively low, but increased slightly from upstream $(0.10 \mathrm{mg} / \mathrm{L})$ to immediately downstream of the CSO $(0.14 \mathrm{mg} / \mathrm{L})$. In terms of ecotoxicology, there were no differences between up-stream and downstream surface water samples in any of the bioassays.

\subsubsection{Benthic Zone}

The increased metal concentrations in the downstream sediments found in our study are consistent with the results of a previous study carried out at the same site [9]. By comparing the contents obtained for the benthic sediments of the Chaudanne with those of other studies (Table 2), we observed that the contents measured upstream of CSO (US4) were of the same magnitude as those measured in the UK [17]. The sediments sampled in Brazil [17] had $\mathrm{Cu}$ concentrations of the same magnitude as for station US6, whereas the study carried out on the Hindon river [19] revealed similar $\mathrm{Cr}$ and $\mathrm{Pb}$ contents. The differences observed between all the different sites can be explained by different land uses and by river flow rates.

A comparison of the concentrations measured in the benthic sediments with the reference values available in the literature for sediments and, more specifically, for sediments that come from granitic massifs like that of the Chaudanne, revealed increased metal concentrations in 
Table 2. Comparison of $\mathrm{Cr}, \mathrm{Cu}$ and $\mathrm{Pb}$ contents measured in benthic sediments.

\begin{tabular}{cccccc}
\hline Sites & $\begin{array}{c}\text { Chaudanne } \\
\text { Upstream (US4) }\end{array}$ & $\begin{array}{c}\text { Chaudanne } \\
\text { Downstream (DS6) }\end{array}$ & $\begin{array}{c}\text { Charlton Brook } \\
\text { [17] (England) }\end{array}$ & $\begin{array}{c}\text { Cambé stream } \\
\text { [18] (Brazil) }\end{array}$ & $\begin{array}{c}\text { Hindon river } \\
\text { [19] (India) }\end{array}$ \\
\hline $\mathrm{Cr}(\mu \mathrm{g} / \mathrm{g})$ & 18 & 55 & 18 & 6 & 76 \\
$\mathrm{Cu}(\mu \mathrm{g} / \mathrm{g})$ & 5 & 54 & 15 & 48 & 5 \\
$\mathrm{~Pb}(\mu \mathrm{g} / \mathrm{g})$ & 10 & 130 & 31 & 1 & 45 \\
\hline
\end{tabular}

the downstream zone.

The comparison, facilitated by a preliminary calculation of pollution factors ( $\mathrm{pf}=$ sediment concentration/ reference concentration) for each of the metals studied, showed that the metal concentrations in the benthic zone were similar to the reference concentrations at the upstream sites for all three metals.

However, there was a marked increase in the concentrations at site DS6, situated immediately below the CSO (pollution factor of 3.0 for lead and 4.2 for copper), indicating the contamination of the benthic sediments at this site. These high concentrations can be attributed to the CSO discharge coupled with the geomorphology of this site, located on flat ground where the flow rate is low, which encourages metal adsorption on these particles. With regard to the ecotoxicological tests carried out on the "water" and "particle" samples from benthic sediments, differences between the upstream and downstream samples were only apparent in the 6-day Hi test. Indeed, in contrast to the upstream samples, disturbed ostracod growth was observed in those collected at site DS8. This disturbance may, however, be linked to metal concentrations, which were similar at this site to upstream sites.

\subsubsection{Hyporheic Zone}

In contrast to the benthic sediments, the pollution factors (pf) exhibited by the hyporheic sediments were frequently above 2 according to Belamie's chart (1990) [20]. Studies on the sediments of hyporheic zones are rare as the technique used to sample sediments by Bou Rouch pumping is mostly performed by biologists. Feris et al. (2009) [21] measured $\mathrm{Cu}$ contamination levels of about the same magnitude as those observed for station DS6 (220 and $115 \mu \mathrm{g} / \mathrm{g}$ respectivement) whereas the $\mathrm{Pb}$ contents measured were only half those of $\mathrm{Cu}$ (111 and 260 $\mu \mathrm{g} / \mathrm{g}$ respectively.

The analysis of the individual stations indicated strong variations between the hyporheic sediments. The pf values confirmed the sediment contamination at station DS6 located immediately below the CSO. The pf were even higher than 6 for lead and copper, which according to this chart, is an indicator of confirmed pollution. We also noted strong pf for site US4, situated immediately above the CSO (pf lead = 5.9; pf chromium = 4.6) and site US2, the farthest upstream (pf chromium $=3.4$; pf copper $=$
8.2). These concentrations could indicate a bias due to the pumping method used to collect the hyporheic sediment samples. Indeed over-representation of fine fractions in relation to grit, which is naturally low in metals (quartz), would artificially increase the metal content. However, an analysis of $\mathrm{Cr} / \mathrm{Cu}$ and $\mathrm{Pb} / \mathrm{Cu}$ concentration ratios at site DS6 $(\mathrm{Cr} / \mathrm{Cu}=0.65 ; \mathrm{Pb} / \mathrm{Cu}=0.84)$ showed that these ratios differed greatly from the reference concentration ratios: $\mathrm{Cr} / \mathrm{Cu}=1.54$ and $\mathrm{Pb} / \mathrm{Cu}=3.38$ [19]. Upstream station US2 therefore presented signs of copper pollution and, to a lesser extent, chromium. The high concentrations of lead and copper measured at site US4 could be linked to local contamination (drainage ditches, etc.).

The study by Angerville (2009) [9] carried out at the same experimental site also showed increased concentrations of the 3 metals downstream of the CSO. However, the concentrations in our study were much higher than those measured by Angerville. This difference could be attributable to an accumulation over a long period without losses to groundwater through diffusion, and/or by the absence of morphogenic flooding before our sampling campaign, which would have shifted the sediments and evacuated them towards the downstream portion of the basin.

In terms of ecotoxicity, two bioassays differentiated the upstream from the downstream samples: $\mathrm{Bc}$ and $\mathrm{Hi}$. The $\mathrm{Bc}$ test identified the toxic effect of the particle phase, which was greater directly downstream of the CSO. This was probably linked to the high metal concentrations in the sediments, particularly lead ( $\mathrm{pf}=10.9)$.

The Hi test was consistent with the Bc test. A marked growth inhibition was observed for sites DS6 and DS8 compared to upstream.

\section{Conclusions}

Aquatic organisms were only at risk in the two chronic toxicity tests. The benthic and hyporheic zone samples collected immediately downstream of the CSO (DS6), particularly the "particle" phase, presented an ecotoxicological risk for the organisms.

The physico-chemical comparison of the ecotoxicological state of the three zones of the stream (surface water, benthic zone and hyporheic zone) both upstream and downstream of the CSO revealed the significant impact of this runoff on the stream. 
In terms of chemical pollution and through a compareson with the reference concentrations, we found that the benthic sediments collected directly below the CSO contained higher mass $\mathrm{Cr}, \mathrm{Cu}$ and $\mathrm{Pb}$ concentrations than in the upstream area, and a high level of contamination. We found increased pollution factors in the downstream hyporheic samples, indicating that all 3 metals had contaminated the sediments, especially directly below the CSO. The CSO discharge could account for the strong concentrations measured at these sites but further sampling is required to confirm this.

At the end of this study, we have achieved our objecttives concerning the feasibility and the utility of our multi-level approach. Concerning the impact assessment of the CSO on the river, it is necessary to remember that these results were obtained during a single storm, and that the ecotoxicological characteristics can vary according to the storm strength, the event duration, the season sampling, etc. Therefore, we must now repeat the studies and investigate other periods of the year in order to complete the assessment. This will enable us to study the behaviour of pollutants during different hydrologic configurations (accumulation, transfer, etc.) and to identify the periods and zones of the stream most vulnerable to ecotoxicological risk. Moreover, the coupling of "physico-chemical characterisation and ecotoxicological characterisation" carried out in parallel is a good approach to obtain relevant information even though these characterisation realised with few parameters and a battery of mono-specific bioassays reduced.

\section{Acknowledgements}

This study was funded by the Urban Hydrology Field Observatory of Lyon (Observatoire de Terrain en Hydrologie Urbaine, OTHU) and the CES 2008 "Invasion" project from ANR (French National Research Agency).

\section{REFERENCES}

[1] S. Le Coustumer, P. Moura, S. Barraud, B. Clozel and J. C. Varnier, "Temporal Evolution and Spatial Distribution of Heavy Metals in a Stormwater Infiltration Basin-Estimation of the Mass of Trapped Pollutants," Water Science and Technology, Vol. 56, No. 12, 2007, pp. 93-100. doi:10.2166/wst.2007.761

[2] M. S. Buffleben, K. Zayeed, D. Kimbrough, M. K. Stenstrom and I. H. Suffet, "Evaluation of Urban Non-Point Source Runoff of Hazardous Metals Entering Santa Monica Bay, California," Water Science and Technology, Vol. 45, 2002, pp. 263-268.

[3] R. Angerville, M. Saulais, E. Emmanuel and Y. Perrodin, "Physicochemical and Ecotoxicological Characteristics of Urban Wet Weather Effluents (UWWE) from a French Site," 20th Annual Conference of Association for Environmental Health and Sciences (AEHS), San Diego,
2010.

[4] European Community, "EU Water Framework Directive: Directive 2000/60/EC of the European Parliament and of the Council Establishing a Framework for Community Action in the Field of Water Policy," Office Journal of European Communities, L327, 23 October 2000, pp. 1-72.

[5] C. Becouze-Lareure, "Characterisation and Estimation of Loads of Priority Pollutants in Urban Wet Weather Discharges for Two Experimental Catchments," Ph.D. Thesis, INSA of Lyon, Lyon, 2010.

[6] H. C. Holten Lutzhoft, E. Eriksson and L. Scholes, "Database Presenting Basic Information about EU WFD Priority Substances," Report, 2008, 32 p.

[7] P. Willems, A. Guillou and J. Beirlant, "Bias Correction in Hydrologic GPD Based Extreme Value Analysis by Means of a Slowly Varying Function," Journal of Hydrology, Vol. 338, 2007, pp. 221-236.

[8] J. Marsalek, Q. Rochfort, T. Mayer, M. Servos, B. Dutka and B. Brownlee, "Toxicity Testing for Controlling Urban Wet-Weather Pollution: Advantages and Limitations," Urban Water, Vol. 1, No. 1, 1999, pp. 91-103. doi:10.1016/S1462-0758(99)00006-0

[9] R. Angerville, "Ecotoxicological Risk Assessment Related to the Discharge of Urban Wet Weather Effluent (UWWE) in the Streams: Case Study for a French City and an Haitian City," Ph.D. Thesis, INSA of Lyon and Ecole Nationale des Ponts et Chaussées, Lyon, 2009.

[10] C. Bou and R. Rouch, "Un Nouveau Champ de Recherches sur la Faune Aquatique souterraine," Comptes Rendus de L'Académie des Sciences, Vol. 265, 1967, pp. 369-370.

[11] C. Boillot, C. Bazin, F. Tissot-Guerraz, J. Droguet, M. Perraud, J. C. Cètre, D. Trépo and Y. Perrodin, "Daily Physicochemical, Microbiological and Ecotoxicological Fluctuations of a Hospital Effluent According to Technical and Care Activities," Science of the Total Environment, Vol. 403, No. 1-3, 2008, pp. 113-129.

doi:10.1016/j.scitotenv.2008.04.037

[12] Y. Perrodin, M. Babut, J. P. Bedell, M. Bray, B. Clément, C. Delolme, A. Devaux, C. Durrieu, J. Garric and B. Montuelle, "Assessment of Ecotoxicological Risks Related to Depositing Dredged Materials from Canals in Northern France on Soil," Environment International, Vol. 32, No. 6, 2006, pp. 804-814. doi:10.1016/j.envint.2006.05.003

[13] L. Volatier, C. Bazin, C. Durrieu, I. Gaillard, I. Mokraoui-Boucherif and Y. Perrodin, "Assessment of Marine Dredged Sediments Toxicity for Their Re-Use as Fill Materials: Step 1: Comparative Responses to a Battery of Mono-Specific Bioassay," International Symposium on Sediment Management, Casablanca, 2010.

[14] N. Chèvre, "Etude et Modélisation des Effets Ecotoxiques d'un Micropolluant Organique sur Daphnia Magna et Pseudokirchneriella subcapitata," Ph.D. Thesis, Ecole Polytechnique Fédérale de Lausanne, Département de Génie Rural, 2000.

[15] N. Cauzzi, "Evaluation de l'éco-Compatibilité de Sédiments Contaminés, Traités et non Traités par un Procédé Physico-Chimique, Dans le Cadre d'un Scénario de Dépôt en gravière-Etude en Microcosmes Aquatiques," 
Ph.D. Thesis, INSA of Lyon and LSE-ENTPE, Lyon, 2007.

[16] P. Namour, T. Fournier, F. Thollet, M. Lagouy and P. Breil, "Métrologie des Hydrosystèmes et Méthodologies D'observations-Présentation du Site de Grézieu-laVarenne de l'Observatoire de Terrain en Hydrologie Urbaine," Techniques Sciences Méthodes, Vol. 2, 2008, pp. 33-48.

[17] M. Robson, K. Spence and L. Beech, "Stream Quality in a Small Urbanised Catchment," Science of the Total Environment, Vol. 357, No. 1-3, 2006, pp. 194-207. doi:10.1016/j.scitotenv.2005.03.016

[18] J. S. Almeida, P. C. Meletti and C. B. R. Martinez, "Acute Effects os=f Sediments Taken from an Urban Stream on Physiological and Biochemical Parameters of the Neotropical Fish Prochilodus lineatus," Comparative Biochemistry and Physiology Part C: Toxicology \& Pharamacology, Vol. 140, No. 3-4, 2005, pp. 356-363. doi:10.1016/j.cca.2005.03.004

[19] S. Suthar, A. K. Nema, M. Chabukdhara and S. K. Gupta, "Assessment of Metals in Water and Sediments of Hindon River, India: Impact of Industrial and Urban Discharges," Journal of Hazardous Materials, Vol. 171, No. $1-3,2009$, pp. 1088-1095.

doi:10.1016/j.jhazmat.2009.06.109

[20] R. Belamie, "Methodology of a Study of Sediment Contamination by Metals: Consideration of Reference Standards and of Their Variability," Report, Cemagref of Lyon, Lyon, 1990.

[21] K. P. Feris, P. W. Ramsey, S. M. Gibbons, C. Frazar, M. Rilig, J. Moore, J. Gannon and W. Holben, "Hyporheic Microbial Community Development Is a Sensitive Indicator of Metal Contamination," Environ Science Technology, Vol. 43, No. 16, 2009, pp. 6158-6163.

doi:10.1021/es 9005465 